\title{
Regional Developmental Problems of the Rural Settlements in Bosnia and Herzegovina
}

\author{
Rahman Nurković, Nusret Drešković \\ Faculty of Science, Sarajevo, Bosnia and Herzegovina
}

\begin{abstract}
The paper considers developmental problems of the rural settlements in Bosnia and Herzegovina, which are results of long-term disparity in the regional development in the period 1991-2012. In this paper it is considered the recent migration from rural to urban areas and the depopulation of the rural areas. The result of these trends reflects the development of the new infrastructure and tertiary activities. In these investigations, statistical data processed and geovisualised in GIS were used. The obtained data indicate extremely unequable regional arrangement of the population in the rural areas and socio-economic development.
\end{abstract}

Keywords: Bosnia and Herzegovina, rural settlements, age structure, migration, war, depopulation, transition countries

\section{Methods of Work and Data Sources}

Methodological approach is imperatively adjusted to the purpose of this paper, developmental problems of the rural settlements in Bosnia and Herzegovina, which have a strong influence on local and rural development. The research has been considered through local and rural development of the areas in Bosnia and Herzegovina. In estimation of economic contribution of rural activities to economy, quantitative methods in the range from stochastic to deterministic are almost exclusively used. Of stochastic methods, the most commonly used methods are econometric methods based on the analysis of time series, cross-sectional and panel data. Deterministic methods include models of gravitation (which can partially be stochastic models as well), input-output (IO) analysis and social accounting matrix (SAM), satellite account of tertiary activities and computable general equilibrium (CGE) model (Hara, 2008).

With regard to contents and inclusion into a system on social accounting, evaluation of direct contribution of activities to local and rural development of economy in Bosnia and Herzegovina is a good basis for defining and application of the models that enable consideration of the total contribution of rural activities. Namely, with a direct contribution of tertiary activities perceiving the influence of tertiary activities on local and rural development is more complete, as well as extension of the analysis through considering the links between the sectors that directly sell the services and products of rural activities and those activities servicing these sectors

Rahman Nurković, Full Professor, Department of Geography, Faculty of Science.

Nusret Drešković, Assistant Professor, Department of Geography, Faculty of Science.

Correspondence concerning this article should be addressed to Nusret Drešković, Zmaja od Bosne 33/35, Sarajevo, 71.000, Bosnia and Herzegovina. E-mail: nusret2109@gmail.com. 
(indirect effects of tertiary sector); and is also necessary to consider the influence of increase in income on the economy due to consumption of tertiary activities (induced effects of tertiary activities). In the series of the mentioned methods by which it is possible to perceive the total or partial influence of tertiary activities on economy, the models based on input-output analysis are particularly distinguished, as well as the models of computable general equilibrium (Zhao, Yanagida, Chakravorty, \& Leung, 1997). Input-output analysis is widely applied as the means of estimation of total effects of rural activities; however, one should bear in mind also its limitation as the means of estimation of net effects of development activities on economy of local and rural development in Bosnia and Herzegovina. Input-output analysis is based on the assumptions on fixed prices and fixed coefficients and may result in overestimation of economic effects of tertiary activities on local and rural development.

With input-output analysis only positive effect of rural activities on economic activity is perceived, with neglecting the negative effects that may be bigger than the positive ones. The shortcomings of input-output analysis initiated bigger and bigger use of the computable general equilibrium model as a set of equations that describe production, consumptions, trade, and country's activities (Dwyer, Forsyth, \& Spurr, 2004; Blake, Gillham, \& Sinclair, 2006). Contributing in different ways to economic understanding of tertiary activities, computable general equilibrium models indicate that, due to influence on prices of factors and real appreciation of course, the influences of tertiary activities on the sectors related to tertiary activities are smaller than they are anticipated by input-output models, and, at the same time, they also enable consideration of negative effects of tertiary activities on other sectors competing for these factors (Blake, 2009).

Unequal regional development is a common regularity of development of rural activities, which is particularly expressed, in specific developmental stages, in polarization of economic activities, population, and income. On the basis of these, they have a smaller number of employed persons and, on the whole, less developed tertiary activities. Influence of tertiary activities on local and rural development in Bosnia and Herzegovina requires the use of particular methods. Therefore, studying the general methods and the way of methodology of urban and rural geography in a combination with regional geographic approach will be applied. As a basic method of gathering the sources of primary data, the interview method was used, i.e., depth interview, at which a major instrument was a reminder for interview. About 20 economic activities in Bosnia and Herzegovina were examined. The research was also completed by the analysis of the contents of secondary sources, interpretation and description of the adequate data bases of the Agency for Statistics of Bosnia and Herzegovina.

\section{Introduction}

In contemporary period of economic-geographic development around $35 \%$ of rural population live in rural space of Bosnia and Herzegovina. Most of the rural space takes increasingly characteristics of clear lagging behind in development, which represents a significant negativity of all demographic, sociocultural, and spatial planned indicators. With a change of socio-economic system into market economy, rural space of Bosnia and Herzegovina is facing new challenges. In today's world, boundaries between cities and villages are erased by processes of urbanization and industrialization. Many of applied technology achievements like road and rail routes, electric power, telephone network and other increasingly bring, among other, industry, different 
warehouses of goods, recreation zones and similar to rural areas.

In all this, more and more intensive development of contemporary economic activities is also particularly expressed. At the same time, new research areas that may be added to the previous ones are being gradually developed including, in particular, works from the field of the geography of food, which examines the connections among production, consumption, and presentation (Goodman, 2001), farming cultures (Moris \& Evans, 2004), and the facilities in rural space and bringing together experiences of rurality (Little \& Leyshon, 2003). For needs of this paper, our focus will, therefore, be shifted away from the wider context of rural changes towards agrarian production as an element that has been deemed as a compatible function of rural spaces of Bosnia and Herzegovina.

In this paper, among other, it has been emphasized that every rural area in Bosnia and Herzegovina represents a particular individuality and distinctiveness. The paper itself has been divided into three parts. In the first part, an application of a new institutional theory, in the sense of analyzing the rural space as a product of contemporary economic development, has been discussed. In the second part, a context of development of social and economic restructuring of rural spaces in Bosnia and Herzegovina, as a subject of analysis at the village level, has been discussed. The third part represents a discussion over a process of improvement in transportation in rural settlements, and the method in which the process itself has been shaped by the state and social institutions has also been presented and analysed. Finally, conclusions were made in order to emphasize the role of institutions in an interaction between rural spaces and rural economy, and to stimulate the changes in rural economy of Bosnia and Herzegovina (Nurković, 2012a).

\section{Rural Space as a Product of Contemporary Economic Development}

In the rural space of Bosnia and Herzegovina, numerous and complex economic processes are ongoing, such as the ownership processes, land use, growing agricultural cultures, then the method of exploitation of forest areas, development of industry and tourism and other. All of this has forced its inhabitants to increasingly adjust that space by creating better living conditions and to achieve the living standard level like that of urban environments. In Bosnia and Herzegovina, more and more rural spaces are invested into building of infrastructure, education, employment, rental of land and buildings, industry, tourism, and capital market. Perspectives indicate that rural environment changes in Bosnia and Herzegovina, also that these changes are the result of series of factors, including influence of agriculture in general, of forestry and primary production and the influence of urbanization and accelerated construction. A consequence of this is an accelerated development of tourism and activities that are conducted during free time, as well as care for protection of environment and the processes originating out of the rural space (Nurković, 2010).

Modern agriculture in rural spaces is in conflict with natural environment. Traditional growth of agricultural goods has always been dependant on nature, and constrained with land type, climate, and topography. It has been, therefore, handed over to mercy of weather, pests and different diseases. For pioneers of modern agriculture, however, these constraints and risks represent a loss of capital and they started to use new technologies for control, manipulation and changing the conditions of environment. From old represented techniques, such as irrigation and selective growth, through improvement on slopes and land, up to advanced biotechnology and an application of agricultural chemicals, agricultural practise has developed to level that has changed environment in order to improve productivity of agricultural production in Bosnia and Herzegovina. 
Lack of investment in rural spaces of Bosnia and Herzegovina results in degradation of farms and households; small clusters of houses or small mobile houses are in dilapidated condition, on the other hand emptying out the cities is present with emptied shop-windows and slow destruction of infrastructure, and deserted factories mines and mills (Lorber, 2010).

In 2012, Bosnia and Herzegovina had 5,825 settlements. Medium size settlement had 751 inhabitants, but only when centres of municipalities or, for example, only 12 , for our frames, large cities were excluded. In centres of the municipalities, in the same period lived 1,713,108 inhabitants, and in all remaining 5,716 settlements, there were on average 459 inhabitants. That is a size of an average village of Bosnia and Herzegovina. Rural settlements in Bosnia and Herzegovina represent a basic form of socio-economic organization of the population dealing with agricultural production. In Bosnia and Herzegovina, they appeared and developed next to arable land, respectively where conditions for dealing with agriculture existed. Rural settlements of Bosnia and Herzegovina are, in general, mostly with a small number of inhabitants. They are divided into livestock and agricultural settlements. Livestock settlements are located in mountainous section, they have a poorly developed network of roads and are slowly urbanised. Agricultural settlements appeared by edges of arable land, so that arable land was touched.

Unfavourable development processes in rural areas are most directly noticeable in a negative demographic trend, depopulation, and a reduction of general population density caused by it. That regularity is confirmed also by a higher index of depopulation of rural areas in 2012. Analysis of the mentioned data shows that changes of age structure of population of Bosnia and Herzegovina include two fundamental components (Horvat, 2010).

These are an accelerated reduction of young population share (0-19 years old), that makes somewhat more than a fourth of population of Bosnia and Herzegovina in 2012 (in contrast to 1991 when it made a third), and a significant increase in old population share (more than 60 years old), which is higher than $17 \%$. With this, population of Bosnia and Herzegovina is not categorized as old population (see Table 1 and Figure 1).

Table 1

Age Groups of Population of Bosnia and Herzegovina, of Urban and Other Settlements in 2012

\begin{tabular}{llll}
\hline Age group & $0-19$ years old & $20-59$ years old & 60 and over \\
\hline Urban settlements & $26.2 \%$ & $54.9 \%$ & $17.4 \%$ \\
Rural settlements & $26.7 \%$ & $58.3 \%$ & $15.0 \%$ \\
Bosnia and Herzegovina & $25.6 \%$ & $54.1 \%$ & $20.3 \%$ \\
\hline
\end{tabular}

Note. Source: Statistical Annual of Bosnia and Herzegovina, the State Agency for Statistics of Bosnia and Herzegovina, Sarajevo, 2012.

This also prevents establishment of an active land market, which furthermore enables the farmers to purchase and use modern technology and knowledge, thus having benefit from market economy. In addition, only $0.4 \%$ of land is irrigated. All of these are the reasons for low competitiveness of agricultural sector of Bosnia and Herzegovina. Crop production accounts for $54 \%$ of cultivated land, with wheat and maize as the most important crops. Forage crops account for $29 \%$, vegetables $15 \%$, and industrial crops only $2 \%$. For this reason, major occupations of population in rural spaces of Bosnia and Herzegovina have always been agriculture and cattle breeding until development of industry and other non-agricultural activities, which developed successfully after the Second World War. 


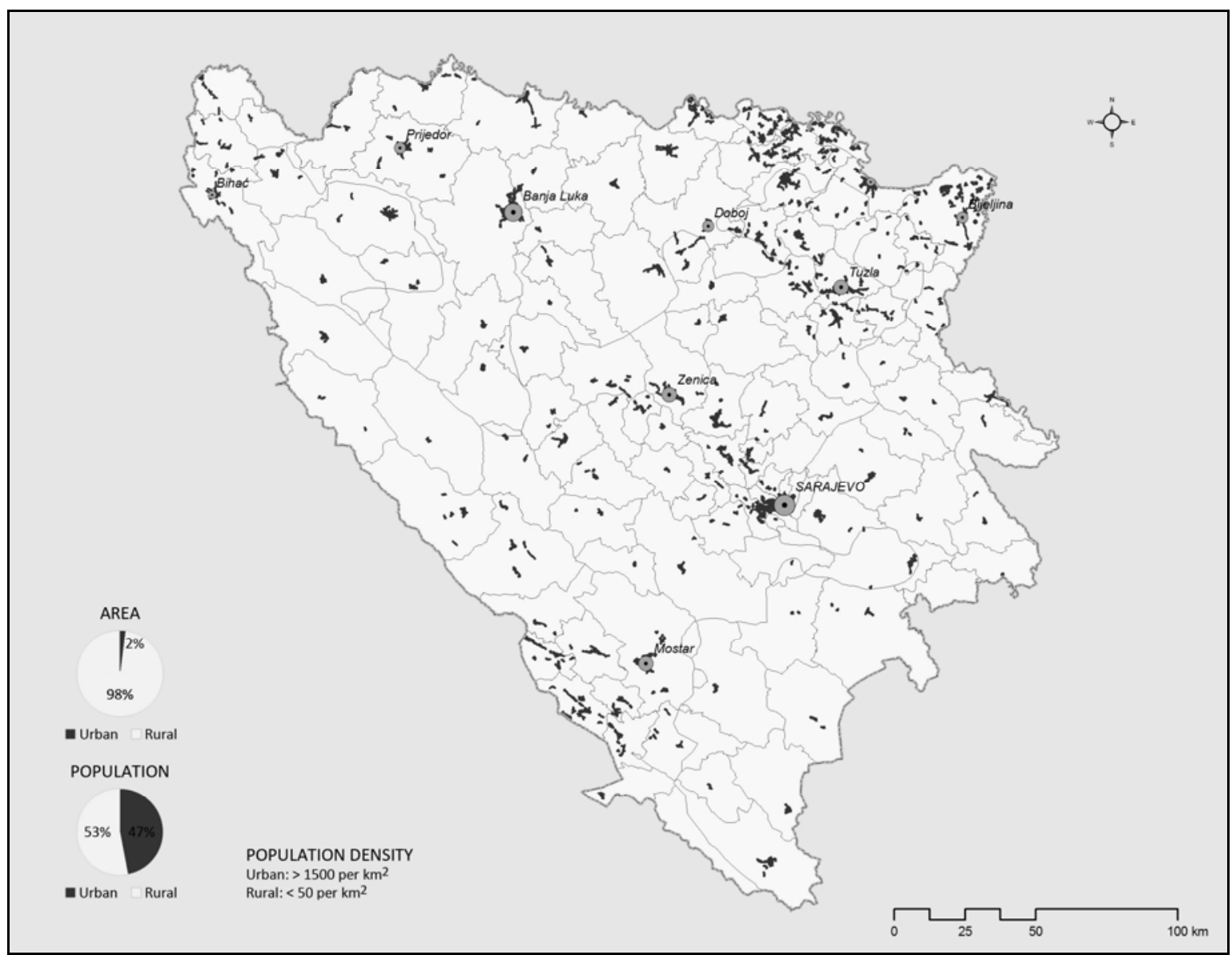

Figure 1. Distribution of agricultural land in Bosnia and Herzegovina in 2012. Authors: Nurković and Drešković.

Rural areas of Bosnia and Herzegovina make over $90 \%$ of its territory. These areas have been exposed to degradation processes since the mid-19th century, and particularly during the socialist economic system since the mid-20th century, from the 1950s to the 1990s, with transition in the past 10 years and during the war from 1992 to1995, which lead to threshold of dying out of the rural, a village as a basic element of rural space. Civilization and historical processes of deagrarization, deruralization, industrialization, and urbanization are present in specific stages of development all over the world and have extremely selective and negative influence on development of the village of Bosnia and Herzegovina. Even around $75 \%$ of rural areas of Bosnia and Herzegovina were characterized by pronounced lagging behind in development in 2011, which designates a clear negativity of all demographic, socio-cultural and spatio-planned indicators. Frequently isolated from the traffic routes, with old age of population and predominant share of elderly and women's population, these areas are dying out fast. Only $30 \%$ of rural areas of Bosnia and Herzegovina are in stagnation-an average type of development that is characterized by a series of favourable prerequisites for faster, easier, and more rational managing the processes and relations (Woods, 2009).

Rural space of Bosnia and Herzegovina has lately been affected by economic impoverishment and insufficient communal and social infrastructure. Fragmented and non-rationally plotted holdings (agricultural land and forests), are unprofitable and do not offer an opportunity for development of commercial farming. Even the holdings that are oriented towards quantity and have needed prerequisites are facing a big competition 
in the market. Development and entry of new, non-agricultural activities into rural space, frequently is not a planned process but a consequence of impossibility of making a living from dealing with primary sector activities. At the same time, a social reputation of a peasant is decreasing. A whole series of factors lead to such situation, which marked development of a village and rural space of Bosnia and Herzegovina in the past, primarily since the mid-19th century and abolition of serfdom, until today.

Revitalization of a village in Bosnia and Herzegovina, in the sense of sustainable and overall development is an indispensable process of preservation of rural spaces as primary production areas of food and other goods, areas of a specific anthropogenic landscape with pronounced natural, traditional, cultural and historical elements, oases of greenery and ecological balance, and finally as areas of tranquillity and rest from dynamical and stressful urban milieu. Tourism in rural space is one of the factors that may have an essential role in renewal and sustainable development of a village (Drešković \& Đug, 2009). In Bosnia and Herzegovina, there is a certain level of unofficial employment; therefore, all data on official employment should be carefully interpreted. The share of unofficial sector in total employment in Bosnia and Herzegovina has increased from $37 \%$ to $42 \%$ in the period between 2001 and 2012. Unofficial employment is largely concentrated in agriculture sector with more than $50 \%$, with a big number of self-employed workers and their family members working with them.

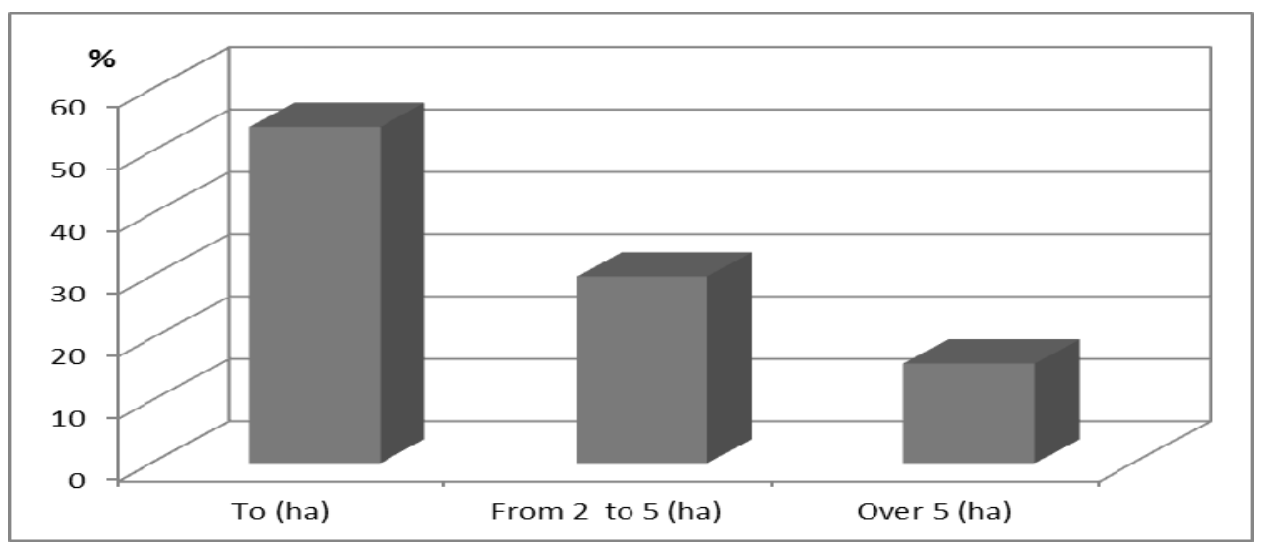

Figure 2. Structure of farms in Bosnia and Herzegovina according to area in hectares, 2012.

Bosnia and Herzegovina has 2,450,000 of hectares of agricultural land which are $48 \%$ of total area, of which arable land accounts to one million hectares, orchards 36,000 hectares, vineyards 4,000 , while the rest of 470,000 make meadows and pastures with 935,000 hectares. This means that agricultural land represents a deficient resource, which should be treated very carefully, in order to achieve as much of added value as possible ( 0.26 ha of arable land available per capita, respectively 0.51 ha of agricultural land). In spite of that, more than $40 \%$ of agricultural land is still unused. It is very important to emphasize an extremely unfavourable structure of agricultural holdings in the sense of their sizes (see Figure 2). The average size per holding is 3.1 ha, and the holdings are, on average, divided to seven to nine plots, which represents a basic element that slows down the faster modernization of this sector.

Rural areas, in which agriculture dominates, are dominant in agriculture in the sense of land use and in economic sense as well. These agrarian, rural areas in Bosnia and Herzegovina contain two subcategories:

- Areas, in which agriculture has a strong structure of production, high productivity and in which industry of cultivation has an important role, can be found in North Bosnia. Socio-economic sustainability is moderate or 
high. An intensified agriculture puts the environment and landscape under high pressure.

- Areas, in which agriculture is a traditional activity, have a weak production structure. Weak productivity is present in Posavina, Herzegovina and in most of the places of Central and East Bosnia. Their socio-economic sustainability is poor. Environment and landscape are under weak pressure.

Processes of restructuring the rural areas in Bosnia and Herzegovina were taking place with different intensity and with spatially differentiated effects, in dependence of interdependent influence of more factors. Among these, fundamental importance had three factors:

- Developmental specificities caused by differences in socio-political system until the beginning of transition (central planning in former communist countries, respectively a combined planned market economy in the area of ex Yugoslavia);

- The method of deconstruction of collectivistic systems of the complex state formations (peacefully or in war);

- Recent position of single states within the European integration processes.

Development of industrialisation in Bosnia and Herzegovina has caused the deep structural changes in the period after the Second World War, which resulted in complex socio-economic transformation, with corresponding consequences in structure of population, functional and physiognomic characteristics, and the environment of rural areas. Widely initiated, urban-based industrialisation has been followed by an intensive social restructuring of farmers and deagrarisation, and related to this, rural exodus as well. During the 1950s, in the intercensus period from 1953 to 2012, a number of farmers declined by around $24,539,271$ or $79.5 \%$. In this context, it is necessary to mobilize the unused resources (human and natural $-40 \%$ of arable land is not used) in order to introduce new technologies for the chosen production lines and adopt a modern business philosophy according to which a consumer is in epicentre of business operation. The first step in this direction is to stimulate the farmers (but also the population from other activities) to develop or to stimulate young people to develop business activities in this sector. This will lead to development of local labour capacities (social capital) indispensable for drawing on the structural funds of the European Union.

A better and sustainable use of human and natural resources is necessary. If this sector succeeded in using at least a half of the unused land in Bosnia and Herzegovina it might employ 20,000-25,000 of new workers only in rural areas (primary food production). If Bosnia and Herzegovina manages to establish a quality safety system in accordance with the requirements of the European Union and the global market, agricultural sector could start an export production of the products of animal origin, meat, milk, and fish, which would lead to a significant reduction in trade deficit that is estimated to be around 100 million KM. Development and strengthening of the other economic activities, as an integral part of rural economy, like accommodation capacities and tourist industry, and different services of narrower scope, would definitely create new jobs in rural areas and improve quality of life of rural communities and result in reduction of import of low-quality food, and by this, improve the quality of nutrition of the major part of population of Bosnia and Herzegovina. This will improve a health condition of the population, thus reducing costs of health and social protection.

\section{Socio-economic Transformation in Rural Areas}

Social and economic restructuring the rural spaces in Bosnia and Herzegovina turned a village in a much more complex space than it used to be. Most of these developmental problems appeared in the period of polarized country's development and spatial differentiation of rural areas caused by it, until the beginning of 
the 1990s (Jordan, 2009).

Unfavourable developmental processes were additionally intensified by the war events during the first half of that decade, by which rural periphery was deeply destabilized. This showed the characteristics of crisis in demographic, regional, and socio-geographic development of peripheral areas, of which a significant part was affected by an extreme rural ruination. Urbanisation process made itself become one of the problems in rural areas of Bosnia and Herzegovina. Comprehensive building plans applied at the end of the 20th century included substantial changes in rural space, which potentially affected a number of people in environment. Planners and many other experts think that land availability and a relatively scarce population density made rural areas become attractive locations for construction of a large number of buildings, which, more or less, cause damage to environment. Transformation that has happened at the end of the 20th century reflects in replacement of such "rural policy" with a new "policy of rural", in which only the meaning and management of rural space is a key question. There is a tendency of intersecting the rural spaces by roads and railways, which mostly connect the major regional centres in Bosnia and Herzegovina. Also, construction of accumulation lakes and dams has so far been, and will be, a part of rural economy based on exploitation of natural rural resources (Woods, 2009).

Hydroelectric sources of Bosnia and Herzegovina appear as surface water courses, underground waters, waters of the Adriatic Sea, and lake waters. This is a result of climate characteristics and geologic and geographic factors. Total technologically usable power of water resources is estimated to 17.7 billion $\mathrm{kWh}$. However, degree of water power utilisation around $20 \%$ of total hydroelectric potential is considered to be very low. This requires examining the responses to rural restructuring that was accepted by responsible people for management of rural areas and of those living in rural areas, before the final research on experiences of changes and on a modern village, by the people from all parts of rural population in Bosnia and Herzegovina (see Figure 3).

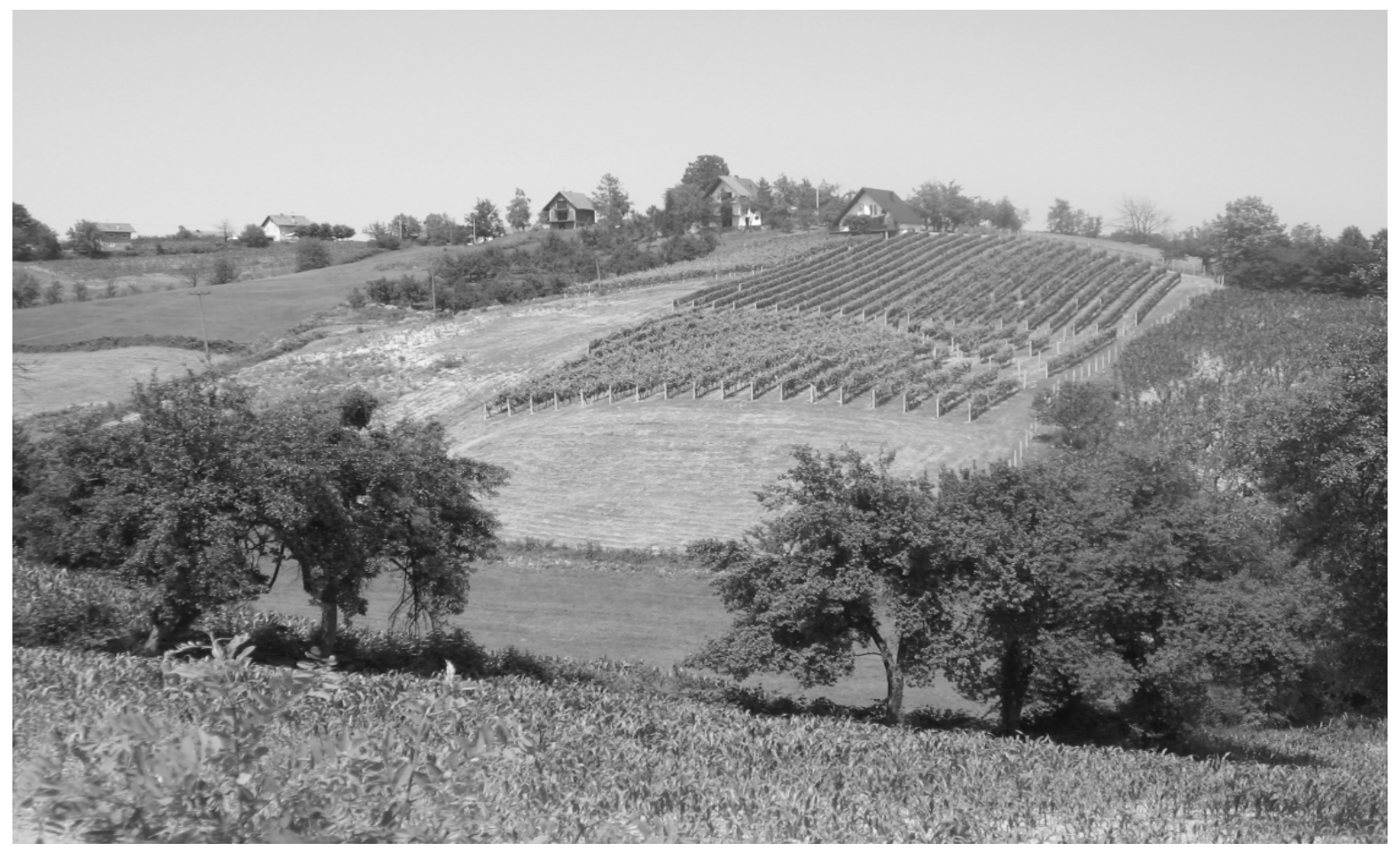

Figure 3. Mini-plantation of vines near Srebrenik 2013. 
Economic changes in rural areas of Bosnia and Herzegovina are demonstrated in several elements. These are:

- Reduction in agricultural enterprises and a number of employed people in agriculture;

- Accompanying structural changes in agriculture and in the labour market in general (key factor: nonexistence of possibility for employment on the farms), specialization, professionalism in agriculture, increased non-agricultural employment — or rural poverty, sustainable production, abandonment a village,

- Influence of globalization: competing pressures and an additional place for expansion of market (new services in rural environments, marketing, and local production, connection with tourism, gastronomy (Jordan, 2009).

The presented aggregate indicators conceal the real, significantly more expressed differences in intensity of depopulation of the single parts of rural space. This is confirmed by an index of a change of number of population in the observed period on Bosnia of Herzegovina of $63.0 \%$. More unfavourable demographic processes than those of the state average in rural areas are additionally corroborated by recent dynamics of population, differences in depopulation rate from 2001 to 2012, and increase in differences in general population density in 2012. The situation is getting more and more complex, as well as monitoring and a significant lagging behind of the employed in development-propulsive and more income-based tertiary sector. The presented dynamical and structural lagging behind of rural areas is directly expressed in cultural landscape of periphery, in its spatial-functional and morphologic-physiognomic characteristics. This is also corroborated by the selected indicators of social-geographic development, share of uncultivated agricultural land, average size of a settlement, and share of abandoned apartments (see Table 2).

Table 2

Share of Agricultural Workers in Bosnia and Herzegovina in 2012

\begin{tabular}{|c|c|c|c|c|c|}
\hline \multirow{3}{*}{ B \& H } & & FAO & The World Bank & $\begin{array}{l}\text { Farms in private } \\
\text { ownership }\end{array}$ & Ownership of land \\
\hline & $\begin{array}{l}\text { Labour force in } \\
\text { agriculture per } \\
1,000 \text { inhabitants }\end{array}$ & $\begin{array}{l}\text { Labour force in rural } \\
\text { spaces }(\%)\end{array}$ & $\begin{array}{l}\text { Labour force in } \\
\text { agriculture }(\%)\end{array}$ & $\begin{array}{l}\text { Agricultural households } \\
\text { per } 1,000 \text { inhabitants }\end{array}$ & $\begin{array}{l}\text { Companies and family farms } \\
\text { with more than five ha (per } \\
1,000 \text { inhabitants ) }\end{array}$ \\
\hline & 85 & 4 & 18 & 290 & 110 \\
\hline
\end{tabular}

Note. Source: The State Agency for Statistics of Bosnia and Herzegovina, Sarajevo, 2012.

Lagging behind the development of rural areas is also confirmed by evidently unfavourable social-economic structure of population against the average of Bosnia and Herzegovina. That disadvantage is contained in almost double share of the employed people in primary sector activities, and, at the same time, a significantly smaller share of the employed people in tertiary sector activities. Although an orientation towards primary sector activities is bigger, first of all, towards agriculture, which is partially predisposed also with spatial structure of rural areas marked with dominance of agricultural land, this fact at the same time, indicates to their lagging behind in the process of transition from traditional agrarian society into a modern industrial and tertiary (service) society (Ruppert, Shiffer, Maier, \& Reinhard, 1977).

\section{Conclusions}

Considering the recent development processes, there is a clear difference between the predominant rural areas and explicit rural areas, where rural areas are distinguished for unfavourable characteristics with most of the observed indicators. Unfavourable characteristics of demographic development of rural areas are expressed 
in higher and higher depopulation rate between 1991 and 2012, lower population density, negative migration balance, higher rate of natural fall, respectively total depopulation rate of old age of population. At the same time, explicit rural areas are separated with a higher degree of economic utilization of population and a higher share of employed people in primary sector against the average of rural areas. Due to higher existential dependence on development, rural areas are generally characterised by smaller share of uncultivated agricultural land against the average of Bosnia and Herzegovina. In structure of populating the rural areas smaller settlements and a larger part of abandoned apartments for permanent living are dominant, with Herzegovina standing out with, on average, the smallest settlements and the biggest share of abandoned apartments among the regions.

The presented, spatially-differentiated structural and dynamical problems of rural areas of Bosnia and Herzegovina, are the resultant of cumulative influence of different factors, from geographic position (remoteness of the developed central settlement), through regional development, to war events during the first half of the 1990s. At the same time, it is important to emphasize that the existing development problems are different in each single rural area, respectively the consequence of different combination of influences of the mentioned factors, which imposes the need for a differentiated approach to their solving. A prerequisite for such approach is a preparation of exactly determined typology or rural areas at all levels of spatial development, which is one of preferential tasks of geographic branch and geographers, not only in Bosnia and Herzegovina, but also in other transition countries of Europe.

These possibilities come in forms of advanced agricultural production, a larger non-agricultural employment, and expansion of market for the products, increased market of formal loans, increased land values, a better approach to education and health services, and a higher standard of living. Development of transport is mostly driven by political and economic motives. The both served to interests of the state and regional economy rather than to interests of rural population. With all these factors in circulation, improvement of socio-economic conditions is connected with socio-economic differentiation. This made almost impossible to generate a simple conclusion on nature of relationship between improvement of transport and rural economy. At present, rural population of Bosnia and Herzegovina enjoys larger economic opportunities for development, but the life gets more complex.

\section{References}

Blake, A. (2009). The dynamics of tourism's economic impact. Tourism Economics, 3, 515-628.

Blake, A. T., Gillham, J., \& Sinclair, M. T. (2006). CGE tourism analysis and policy modelling. In L. Dwyer, \& P. Forsyth (Eds.), International handbook on the economics of tourism. Cheltenham: Edward Elgar.

Drešković, N., \& Đug, S. (2006). Establishment of protected natural areas in Canton Sarajevo and possibilities for their ecotourism valuation. Annales, Ser. Hist. Sociol., 16, 233-246.

Dwyer, L., Forsyth, P., \& Spurr, R. (2004). Economic impacts of aviation stamp duties. Sustainable Tourism Cooperative Research Centre, Gold Coast, Qld.

Goodman, D. (2001). Ontology matters: The relational materiality of nature and agro-food studies. Sociologia Ruralls, 41, $182-200$.

Griffin, E., \& Ford, L. (1980). A model of Latin American city structure. Geographical Review, 70, 397-422.

Hara, T. (2008). Quantitative tourism industry analysis: Introduction to input-output, social accounting matrix modelling and tourism satellite accounts. Amsterdam: Elsevier, Butterworth-Heinemann.

Horvat, U. (2010). Health resorts and their importance for the development of less developed areas in Slovenia. Journal for Geography, 5(1), 147-157.

Jordan, P. (2009). Development of rural space in post-Communist Southeast Europe after 1989: A comparative analysis. Journal 
of Geography, 4(1), 89-102.

Jurčić, L. (2000). Razvitak input-output analize u Hrvatskoj. Ekonomski Pregled, 51(11-12), 1313-1333.

Little, J. (2003). Riding the rural love train: Heterosexuality and the rural community. Sociologia Ruralls, 43, 401-417.

Little, J., \& Leyshon, M. (2003). Embodied rural geographies: Developing research agendas. Progress in Human Geography, 27, 257-272.

Lorber, L. (2010). New challenges for sustainable rural development in the 21st century. Journal for Geography, 5(2), 6-13.

Moris, C., \& Evans, N. (2004). Agricultural turns, geographical turns: Retrospect and prospect. Journal of Rural Studies, 20, 95-111.

Muller, D. (2000). Der landliche Raum Sudosteuropas in der Transformation. Agrarpopulismus in der Zwichenkriegszeit und Reformstrategien in der 90er Jahren am Beispiel Rumaniens, Aus der Sudosteuropa-Forschung, 12, 55-61.

Nurković, R. (2006). Ekonomska geografija svijeta. Tuzla: Univerzitet, Prirodno-matematički fakultet.

Nurković, R. (2010). Infuence of tertiary activities on transformation of the rural settlements in Bosnia and Herzegovina. Journal for Geography, 5(1), 67-73.

Nurković, R. (2012a). Socio-economic transformation of Bosnia and Herzegovina. In J. Bański (Ed.), Local and regional development-challenges and policy issues (pp. 151-161). Warsaw: Institute of Geography and Spatial Organization.

Nurković, R. (2012b). Urbana geografija svijeta. Sarajevo: Prirodno-matematički fakultet.

Ruppert, K., Shiffer, F., Maier, J., \& Reinhard, P. (1977). Sozialgeographie (pp. 40-42). Braunschweig: Georg Westermann Veriang.

Statistical Yearbook of Bosnia and Herzegovina for 1961. (1961). Sarajevo: The Republic Agency for Statistics.

Statistical Yearbook of Bosnia and Herzegovina for 1971. (1971). Sarajevo: The Republic Agency for Statistics.

Statistical Yearbook of Bosnia and Herzegovina for 1981. (1981). Sarajevo: The Republic Agency for Statistics.

Statistical Yearbook of Bosnia and Herzegovina for 1991. (1991). Sarajevo: The Republic Agency for Statistics.

Statistical Yearbook of Bosnia and Herzegovina for 2001. (2001). Sarajevo: The Republic Agency for Statistics.

Statistical Yearbook of Bosnia and Herzegovina for 2007. (2007). Sarajevo: The Republic Agency for Statistics.

Statistical Yearbook of Bosnia and Herzegovina for 2009. (2009). Sarajevo: The Republic Agency for Statistics.

Woods, M. (2009). Rural geography. London: SAGE Publications.

Zhao, D., Yanagida, J., Chakravorty, V., \& Leung, P. (1997). Estimamating economic impacts from turisam. Annals of Turism Research, 1(24), 76-89. 